\title{
A New Bi-Functional Derivative of Polyethylene Glycol as Molecular Carrier for Eugenol and Ibuprofen
}

\author{
Zacchigna $\mathrm{M}^{*}$, Cateni $\mathrm{F}^{1}$, Drioli $\mathrm{S}^{1}$, Procida $\mathrm{G}^{1}$ and Altieri $\mathrm{T}^{1,2}$
}

${ }^{1}$ Department of Chemical and Pharmaceutical Sciences, University of Trieste, Italy

${ }^{2}$ School of advanced studies in Sciences, University of Chieti-Pescara, Italy

${ }^{*}$ Corresponding author: Zacchigna M, Department of Chemical and Pharmaceutical Sciences, University of Trieste, Piazzale Europa, 1, 34127 Trieste, Italy, Tel: +39-0405583104, E-mail: zacchign@units.it

Citation: Zacchigna M, Cateni F, Drioli S, Procida G, Altieri T (2015) A New Bi-Functional Derivative of Polyethylene Glycol as Molecular Carrier for Eugenol and Ibuprofen. J Pharm Drug Devel 3(2): 201. doi: $10.15744 / 2348-9782.2 .201$

Received Date: December 18, 2014 Accepted Date: April 21, 2015 Published Date: April 23, 2015

\begin{abstract}
Eugenol (EU) and ibuprofene (IBU) were covalently bound to a bi-functionalized PEG, used as molecular carrier of drugs and the release kinetics of the two bioactive molecules was studied in vitro in buffer solution at pH 7.4, in simulated gastric fluid and in mouse plasma. The hydrolysis studies showed a specific cleavage dependent on the $\mathrm{pH}$ of the medium and by the presence of proteolytic enzymes in mouse plasma. Studies in vitro on the release of the parent drug from this double prodrug in various media, indicate that the adduct may be sufficiently stable to pass intact the gastrointestinal tract and release into the circulation EU and IBU. Many advantages may be achieved by the synthesis of the prodrug EU-PEG-IBU related to synergistic analgesic and anti-inflammatory effects, to the reduction of the adverse reactions and the improvement of the chemical-physical properties of the parent drugs.
\end{abstract}

Keywords: Macromolecular prodrug; Bi-functional PEG; Ibuprofen; Eugenol; Drug release

\section{Introduction}

The PEGylation is defined as the covalent attachment of poly(ethylene glycol) (PEG) chains to bioactive substances. PEGylation has been investigated as drug delivery systems (DDS) for low molecular weight drugs but in this field, despite some interesting results, it has not reached the same success of protein PEGylation. Nevertheless, the development of PEG-small drug conjugates, especially those bearing a targeting residue or a combination of two drugs, is an intense area of research [1]. Methoxy $\mathrm{PEG}, \mathrm{CH}_{3} \mathrm{O}-$ $\left(\mathrm{CH}_{2} \mathrm{CH}_{2} \mathrm{O}\right)_{\mathrm{n}}-\mathrm{H}$, is at the basis of all approved PEGylated products either in its linear or branched form. Two key properties of this polymer are its great flexibility, owing to the absence of bulky substituents along the chain, and the high hydration of the polymeric backbone. Being nontoxic, non-immunogenic, non-antigenic and amphiphilic, PEG has been approved by FDA for human oral, intravenous, and dermal pharmaceutical applications [2].

The conjugation of simple drugs or more complex molecules in synthetic polymers is of great interest in pharmacological applications. The PEG polymer is one of the most widely used for its chemical-physical and biological characteristics in the synthesis of prodrugs [3].

Generally, the design of a prodrug involves the optimization of drug release. A prodrug is a biologically inactive derivative of a drug that usually requires an enzymatic transformation in vivo in order to release the active principle. The use of PEG conjugates and the in vivo release of bioactive molecules has been extensively studied and many practical applications have been found. Other advantages of PEGylation are derived from the increased solubility of the prodrug that leads to a better distribution of the parent drug [4].

An increase of the water solubility, of the half-life time and a reduction of side effects of bioactive molecules can also be obtained through the preparation of polymeric prodrugs. The use of polymers as prodrugs of bioactive agents can reduce the required dose, and therefore the drug toxicity, improving its solubility and therapeutic effectiveness. Moreover, the conjugation to a polymer of a biologically active molecule is one of several methods to modify and control the pharmacokinetics, biodistribution and often the toxicity of these compounds.

The nonsteroidal anti-inflammatory drugs (NSAIDs) are often poorly soluble in water and often cause gastrointestinal side effects such as stomach ulcers, bleeding and perforation.

Ibuprofen, $(\mathrm{R}, \mathrm{S})$ [2-(4-isobutylphenyl) propionic acid] belongs to the class of non-steroidal anti-inflammatory drugs (NSAIDs), acts by inhibiting isoforms of cyclo-oxygenase (COX) 1 and 2. It is used to treat inflammatory rheumatoid diseases and relieves acute pain [5]. It is poorly soluble in water, commonly administered orally, is rapidly absorbed and reaches the maximum plasmatic concentration within 2 hours. However, it has a short biological half-life of 2 hours, which means that frequent doses are required 
to maintain the therapeutic efficacy for prolonged periods of time [6]. Progression in the gastrointestinal (GI) side effects particularly stomach ulceration, bleeding and perforation are the main constraint in its use which is particularly due to local action exerted by direct contact of drug with gastric mucosa [7]. Thus free acidic group plays a key role in maintaining the effectiveness and producing the gastric ulceration [8]. In view of this, various approaches have been used to minimize side effects by masking free acidic group chemically with retaining the potency, like i) the synthesis of ester derivatives of ibuprofen as mutual prodrugs with naturally occurring phenolic and alcoholic compounds [9-11] or ii) the conjugation with PEG with an increase of solubility in water and a prolongation of the pharmacological effects [6].

Eugenol(4-allyl-2-methoxyphenol) is the main component of clove oil (Eugenia aromatic), and is mainly produced in Indonesia. It is widely used in perfumes, as antioxidant, drug, food, and taste items. It is practically insoluble in water and has been used for decades in dentistry for its analgesic properties. Several recent papers reported the anti-diabetic, anti-inflammatory (due to antioxidant activity), vasodilative, anticancer, anesthetic, antibacterial, antiviral [12], and cytoprotective of the gastric mucosa [1316] activities of clove. Furthermore the utility of clove oil as a penetration enhancer, in vitro and in vivo, has been demonstrated [17]. Eugenol is a very promising candidate for versatile applications, and the design of a new prodrug based on the pharmacological effects of eugenol could be beneficial.

In literature several studies report the pharmacological activity of the direct-ibuprofen eugenol prodrug (IEE) without improve the chemical-physical properties [11,18,19]. Zhao et al. [10] synthesized the ibuprofen eugenol ester (IEE), a virtually non soluble highly lipophilic drug, with the aim to reduce the common side effects caused by traditional NSAIDs. The IEE was trapped in a microemulsion to increase the water solubility of the preparation.

The objective of the present paper is s the synthesis of the prodrug EU-PEG-IBU in order to achieve many advantages related to synergistic analgesic and anti-inflammatory effects and to reduction of GI irritation without adverse reactions on their bioactivity and to the improvement the poor water solubility of the compounds.

Furthermore, studies in vitro on the release of the parent drugs from this double prodrug in various media, indicate that the adduct may be sufficiently stable to pass intact the gastrointestinal tract and release into the circulation eugenol and ibuprofen.

\section{Materials}

EU eugenol, IBU ibuprofene, EDC (1,3-ethyl-diaminopropyl carbodiimide hydrochloride), HOBT (N-hydroxybenzotriazole), TFA (trifluoroacetic acid), Pepsin from porcine gastric mucosa, powder, $\geq 250$ units $/ \mathrm{mg}$ solid, Plasma from mouse were purchased from Sigma-Aldrich. Polyethylene glycol diOH-PEG (PEG) (MW = $6000 \mathrm{Da}), N, N^{\prime}$-disuccinimidyl carbonate, succinic anhydride, 1,3-diaminopropane, DCC (N,N'dicyclohexylcarbodiimide), DMAP (4-dimethylaminopyridine) and acetonitrile were purchased from Fluka (Buchs, Switzerland). All the organic solvents were dried over 4 Å molecular sieves.

\section{Spectral analysis}

The spectrophotometric UV/VIS analysis was performed on a Helios $\beta$ UNICAM spectrophotometer.

${ }^{1} \mathrm{H}-\mathrm{NMR}$ spectra were recorded on a Jeol EX400 spectrometer in DMSO- $\mathrm{d}_{6}$ using tetramethylsilane (TMS) as internal standard $(\delta$ $=0.0 \mathrm{ppm}$ ).

ElectroSpray Ionization (ESI) mass spectra were obtained on a PE-API 1 spectrometer by infusion of a solution of the polymeric sample in a $1: 1$ solution of $\mathrm{CH}_{3} \mathrm{OH} / \mathrm{CH}_{3} \mathrm{COONa} 5 \%$ (ionising potential: $5600 \mathrm{~V}$; infusion $0.1 \mathrm{~mL} / \mathrm{h}$; curtain gas $\mathrm{N}_{2}, 1.2 \mathrm{~L} / \mathrm{min}$; nebulizing gas, air $0.6 \mathrm{~L} / \mathrm{min})$.

${ }^{1} \mathrm{H}-\mathrm{NMR}$ and mass spectrometry (ESI-MS and/or MALDI-TOF) data fully confirm the signal assignments and structure of the materials.

\section{Methods}

\section{RP-HPLC analysis}

HPLC analyses were carried out with a Perkin-Elmer HPLC connected to a variable-wavelength UV detector. A LiChrosorb RP18 column $(5 \mu \mathrm{m}, 250 \mathrm{~mm}$ x $4.6 \mathrm{~mm}$ i.d., Perkin-Elmer) was used.

HPLC analysis for EU and IBU were carried out according to the method described by Zhao et al. with some modifications [20]. A mixture of water - acetonitrile - trifluoroacetic acid - tetrahydrofuran (23:55:2:2 v/v), was employed as mobile phase, the detection wavelength was $230 \mathrm{~nm}$ and the flow rate was $1 \mathrm{~mL} / \mathrm{min}$. Quantification was performed on the basis of linear calibration plot of peak area against concentration. Each curve is based on seven concentrations of the standard. Identification of the drugs was made by comparison of the retention times with those of pure standard.

\section{TNBS test}

The amount of free $\mathrm{NH}_{2}$ was calculated using the colorimetric TNBS test [21]. The TNBS analysis was made on 2 mg samples of different compounds, accurately weighted and added to a $10 \mathrm{ml}$ flask with $9 \mathrm{ml}$ of borate buffer $0.1 \mathrm{M}$ (pH 9.3) and with $0.25 \mathrm{ml}$ of a $0.03 \mathrm{M}$ solution of TNBS in the same buffer. The volume was adjusted to $10 \mathrm{ml}$ and after $30 \mathrm{~min}$ the absorbance at $421 \mathrm{~nm}(\varepsilon=$ 12850) gave the amount of free $\mathrm{NH}_{2}$ groups. 
Synthesis of compound 1: The orthogonally protected diamino PEG 1 was thus synthesized according to a method described by Bonora et al. [22].

Yield 40\%.

${ }^{1} \mathrm{H}-\mathrm{NMR}\left(\mathrm{DMSO}_{6}\right.$ ): $\delta=7.32 \mathrm{ppm}(\mathrm{m} ; 5 \mathrm{H}, \mathrm{Ar}-\mathrm{H}), 7.17$ (m; 3H, NH-CO-O), $4.99\left(\mathrm{~s} ; 2 \mathrm{H}, \mathrm{CH}_{2}-\mathrm{Ph}\right), 4.02\left(\mathrm{~m} ; 4 \mathrm{H}, \mathrm{CH}_{2}-\mathrm{O}-\mathrm{CO}-\mathrm{NH}\right)$, 3.53-3.32 (m; 545H, PEG), 2.97 (m; 6H, CH $-\mathrm{NH}-\mathrm{CO}-\mathrm{O}), 1.51\left(\mathrm{~m} ; 4 \mathrm{H}, \mathrm{CH}_{2}-\mathrm{CH}_{2}-\mathrm{CH}_{2}\right)$.

Synthesis of compound 2: Cbz- $\mathrm{NH}\left(\mathrm{CH}_{2}\right)_{3} \mathrm{NH}-\mathrm{CO}-\mathrm{O}-\mathrm{PEG}-\mathrm{O}-\mathrm{CO}-\mathrm{NH}\left(\mathrm{CH}_{2}\right)_{3}-\mathrm{NH}_{2} 1$ (1 eq) was coevaporated with $50 \mathrm{ml}$ of anhydrous dichloromethane (x2) and dried using a rotary pump; this PEG-derivative was then dissolved in the minimum amount of $\mathrm{CH}_{2} \mathrm{Cl}_{2}(10 \mathrm{ml})$ and then reacted with IBU (3 eq), by addition of EDC (3 eq) and HOBT (3 eq), keeping pH around 8.5 (TEA). The solution was stirred for $18 \mathrm{~h}$ at room temperature, precipitated with $50 \mathrm{ml}$ of diethyl ether in an ice-bath and filtered on a Gooch 3 , washed with diethyl-ether and then recrystallized from $100 \mathrm{ml}$ of hot/cold ethanol. The final product (2) was characterized by ${ }^{1} \mathrm{H}-\mathrm{NMR}$ spectroscopy and the amount of free $\mathrm{NH}_{2}$ was calculated using the colorimetric TNBS test. The absence of the free drug in the adduct was confirmed by RP-HPLC. The content of linked drug in the conjugate was evaluated by RP-HPLC, on the basis of the release of IBU in alkaline media after $15 \mathrm{~min}$ at $80^{\circ} \mathrm{C}$. This was found to be $100 \%(\mathrm{w} / \mathrm{w})$.

Yield 95\%.

${ }^{1} \mathrm{H}-\mathrm{NMR}\left(\mathrm{DMSO}-\mathrm{d}_{6}\right): \delta=7.88$ ppm (brs; 1H, NH), 7.34 [m; 5H, Ar H-(Cbz)], 7.21 (m; 4H, Ar H-IBU, J = 7.51, 8.06 Hz], 7.05 $(\mathrm{m} ; 3 \mathrm{H}, 3 \mathrm{NH}-\mathrm{CO}-\mathrm{O}, J=8.04 \mathrm{~Hz}), 5.01$ [s; $\left.2 \mathrm{H},-\mathrm{CH}_{2}-\mathrm{Ph}(\mathrm{Cbz})\right], 4.03$ [m; 4H, - $\left.\mathrm{CH}_{2} \mathrm{OCONH}(\mathrm{PEG})\right], 3.53-3.32$ [brs, 546H, (CH $\left.\mathrm{CH}_{2}-\mathrm{O}\right)_{\mathrm{n}}$-PEG, CH-CH$-\mathrm{IBU}$ ], 2.90-3.05 (m; 8H, $\left.3 \mathrm{CH}_{2} \mathrm{NHCOO}, \mathrm{CH}_{2} \mathrm{NHCO}\right), 2.38$ [d; $2 \mathrm{H}, \mathrm{CH}_{2} \mathrm{CH}\left(\mathrm{CH}_{3}\right)_{2}-\mathrm{IBU}, J=7.14 \mathrm{~Hz}$ ], 1.79 $\left[\mathrm{m} ; 1 \mathrm{H}, \mathrm{CH}\left(\mathrm{CH}_{3}\right)_{2}-\mathrm{IBU}\right], 1.50\left(\mathrm{~m} ; 4 \mathrm{H}, \mathrm{CH}_{2} \mathrm{CH}_{2} \mathrm{NHCO}\right), 1.29$ [d: $\left.3 \mathrm{H}, \mathrm{CH}-\left(\mathrm{CH}_{3}\right)-\mathrm{IBU}, J=6.71 \mathrm{~Hz}\right], 0.85\left[\mathrm{dd} ; 6 \mathrm{H}, \mathrm{CH}(\mathrm{CH})_{2}-\mathrm{CH}-\right.$ IBU, $J=6.56 \mathrm{~Hz}]$.

Synthesis of compound 3: The compound (2) thus obtained was then dissolved in $10 \mathrm{ml}$ of methanol, added of 5\% Pd/C (in a quantity equal to $10 \%$ by weight on the substrate) and $\mathrm{HCl}$ till $\mathrm{pH} 2$, and stirred at room temperature and under hydrogen atmosphere for $16 \mathrm{~h}$. The catalyst was then filtered off through celite and precipitated with $100 \mathrm{ml}$ of diethyl ether in an ice-bath and filtered on a Gooch 3, washed with diethyl-ether and then recrystallized from $100 \mathrm{ml}$ of hot/cold ethanol. The conjugated $\mathrm{NH}_{2}$-linker-PEG-linker-IBU (1 eq), once deprotected following the general procedure described above, was dissolved in $10 \mathrm{ml}$ of anhydrous dichloromethane, added of succinic anhydride (5 eq) and DMAP (2.5 eq). The solution was left stirring at room temperature for $16 \mathrm{~h}$, precipitated with $80 \mathrm{ml}$ of diethyl ether in an ice-bath and filtered on a Gooch 3, washed with diethyl-ether and then recrystallized from $100 \mathrm{ml}$ of hot/cold ethanol. The final product (3) was characterized by ${ }^{1} \mathrm{H}-\mathrm{NMR}$ spectroscopy.

Yield 95\%.

${ }^{1} \mathrm{H}-\mathrm{NMR}\left(\mathrm{DMSO}-\mathrm{d}_{6}\right): \delta=7.90$ ppm (brs; $\left.2 \mathrm{H}, \mathrm{NH}\right), 7.22 \mathrm{ppm}[\mathrm{m} ; 4 \mathrm{H}, \mathrm{ArH}-\mathrm{IBU}, J=7.50,8.05 \mathrm{~Hz}], 7.06$ (m; $2 \mathrm{H}, 2 \mathrm{NH}-\mathrm{COO}, J$ $=7.9 \mathrm{~Hz}), 4.02\left[\mathrm{~m} ; 4 \mathrm{H}, 2 \mathrm{CH}_{2}-\mathrm{OCONH}(\mathrm{PEG})\right], 3.54-3.33\left[\mathrm{~m} ; 546 \mathrm{H},\left(\mathrm{CH}_{2}-\mathrm{CH}_{2}-\mathrm{O}\right)_{\mathrm{n}}-\mathrm{PEG}, \mathrm{CH}-\mathrm{CH}_{3}-\mathrm{IBU}\right], 2.85-3.10[\mathrm{~m} ; 10 \mathrm{H}, 2$ $\left.\mathrm{CH}_{2} \mathrm{NHCOO}, 2 \mathrm{CH}_{2} \mathrm{NHCO}, \mathrm{CH}_{2} \mathrm{COOH}\right), 2.41\left[\mathrm{~d} ; 2 \mathrm{H}, \mathrm{CH}_{2} \mathrm{CH}\left(\mathrm{CH}_{3}\right)_{2}-\mathrm{IBU}, J=7.13 \mathrm{~Hz}\right.$ ], $2.32\left[\mathrm{t} ; 2 \mathrm{H}, \mathrm{CH}_{2} \mathrm{CONH}\right.$ ], $1.82[\mathrm{~m} ; 1 \mathrm{H}$, $\left.\mathrm{CH}\left(\mathrm{CH}_{3}\right)_{2}-\mathrm{IBU}\right], 1.50\left(\mathrm{~m} ; 4 \mathrm{H}, \mathrm{CH}_{2} \mathrm{CH}_{2} \mathrm{NHCO}\right), 1.29$ (d; 3H, CH- $\left.\left(\mathrm{CH}_{3}\right)-\mathrm{IBU}, J=7.32 \mathrm{~Hz}\right], 0.88\left(\mathrm{dd} ; 6 \mathrm{H},\left(\mathrm{CH}_{3}\right)_{2}-\mathrm{CH}-\mathrm{IBU}, J=6.59\right.$ $\mathrm{Hz}]$.

Synthesis of compound 4: The compound 3 (1 eq) was coevaporated with $50 \mathrm{ml}$ of anhydrous dichloromethane (2x) and dried under high vacuum; this PEG-derivative was then dissolved in the minimum amount of anhydrous dichloromethane (8 $\mathrm{ml}$ ) and then reacted with EU (10 eq), by addition of DCC (5 eq) and DMAP (5 eq). The solution was left stirring for $18 \mathrm{~h}$ at room temperature under argon atmosphere, precipitated with $80 \mathrm{ml}$ of diethyl ether in an ice-bath and filtered on a Gooch 3, washed with diethyl ether and then recrystallized from $100 \mathrm{ml}$ of hot/cold ethanol. The final product (4) was characterized by ${ }^{1} \mathrm{H}-\mathrm{NMR}$ spectroscopy.

Yield 94\%.

${ }^{1} \mathrm{H}-\mathrm{NMR}\left(\mathrm{DMSO}-\mathrm{d}_{6}\right): \delta=7.92$ ppm (brs; 2H, NH), 7.27 [m; 4H, ArH-IBU, J = 7.51, 8.06 Hz], 7.08 (m; 2H, $2 \mathrm{NHCOO} J=7.8$ $\mathrm{Hz}), 6.95$ (m; 1H, Ar-H-EU), 6.70-6.75 (m; 2H, ArH-EU, J = 0.6 Hz), 5.90-6.10 (m; 1H, CH-CH=CH $-\mathrm{EU}), 5.06,5.18(\mathrm{dd}, 2 \mathrm{H}$, $\left.\mathrm{CH}-\mathrm{CH}=\mathrm{CH}_{2}-\mathrm{EU}, J=1.5,1.4 \mathrm{~Hz}\right), 4.05\left(\mathrm{~m} ; 4 \mathrm{H}, 2 \mathrm{CH}_{2}-\mathrm{OCONH}(\mathrm{PEG})\right], 3.80$ (s; 3H, CH $\left.-\mathrm{O}-\mathrm{EU}\right), 3.54-3.34$ [m; $548 \mathrm{H},\left(\mathrm{CH}_{2}-\right.$ $\left.\left.\mathrm{CH}_{2}-\mathrm{O}\right) n-\mathrm{PEG}, \mathrm{CH}-\mathrm{CH}_{3}-\mathrm{IBU}, \mathrm{CH}_{2} \mathrm{CH}=\mathrm{CH}_{2}-\mathrm{EU}\right], 2.90-3.10\left(\mathrm{~m} ; 10 \mathrm{H}, 2 \mathrm{CH}_{2} \mathrm{NHCOO}, 2 \mathrm{CH}_{2} \mathrm{NHCO}_{2} \mathrm{CH}_{2} \mathrm{COOH}\right), 2.60\left[\mathrm{t} ; 2 \mathrm{H}^{2}\right.$, $\left.\mathrm{CH}_{2} \mathrm{CONH}\right), 2.39\left[\mathrm{~d} ; 2 \mathrm{H},-\mathrm{CH}_{2} \mathrm{CH}\left(\mathrm{CH}_{3}\right)_{2}-\mathrm{IBU}, J=7.47 \mathrm{~Hz}\right], 1.79\left[\left(\mathrm{~m} ; 1 \mathrm{H}, \mathrm{CH}\left(\mathrm{CH}_{3}\right)_{2}-\mathrm{IBU}\right], 1.49\left(\mathrm{~m} ; 4 \mathrm{H}_{2} \mathrm{CH}_{2} \mathrm{CH}_{2} \mathrm{NHCO}\right), 1.29[\mathrm{~d}\right.$; $3 \mathrm{H},-\mathrm{CH}\left(\mathrm{CH}_{3}\right)-\mathrm{IBU}, J=7.2 \mathrm{~Hz}$ ], 0.85 [dd; $6 \mathrm{H},\left(\mathrm{CH}_{3}\right)_{2}-\mathrm{CH}-\mathrm{IBU}, J=6.60 \mathrm{~Hz}$ ].

\section{In vitro release studies}

Conjugate stability in simulated extra-cellular fluid and in simulated gastric medium: The study was carried out incubating the compound $4(5 \mathrm{mg} / \mathrm{ml})$, in phosphate buffer solution $\left(10 \mathrm{mM} \mathrm{NaH}_{2} \mathrm{PO}_{4}, 0.15 \mathrm{M} \mathrm{NaCl}\right) \mathrm{pH} 7.4$, and artificial gastric juice $(2 \mathrm{~g} \mathrm{NaCl}$, $3.2 \mathrm{~g}$ pepsin powder, $80 \mathrm{ml} \mathrm{HCl} 1 \mathrm{M}$ in 11 of water) $\mathrm{pH} 1.2$. The solutions were incubated at $37 \pm 0.1^{\circ} \mathrm{C}$ and sampled by RP-HPLC analysis at schedule times on the basis of formation of free EU and IBU. The quantity of EU and IBU released by hydrolysis was quantified with the HPLC method previously described. Every experiment was repeated in triplicate. 
Conjugate stability in plasma: The study was carried out incubating the compound $4(5 \mathrm{mg} / \mathrm{ml})$ in mouse plasma at $37 \pm 0.1^{\circ} \mathrm{C}$ for $24 \mathrm{~h}$. At scheduled times samples of $100 \mu \mathrm{l}$ were collected and $900 \mu \mathrm{l}$ of cold ACN were added to each samples. After centrifugation at 12,000 rpm for $3 \mathrm{~min}, 500 \mu \mathrm{l}$ of supernatant was freeze-dried. The obtained residue was dissolved with $50 \mu \mathrm{l}$ of mobile phase and analysed by RP-HPLC analysis as reported above. Every experiment was repeated in triplicate.

IBU: EI-MS (70 eV.): $m / z=206[\mathrm{M}, 27 \%]^{+}, 191\left[\mathrm{M}-\mathrm{CH}_{3}, 11 \%\right]^{+}, 161\left[\mathrm{M}-\mathrm{CO}_{2} \mathrm{H}, 100 \%\right]^{+}$.

EU: EI-MS (70 eV.): $m / z=164[\mathrm{M}, 100 \%]^{+}, 149\left[\mathrm{M}-\mathrm{CH}_{3}, 22 \%\right]^{+}, 137\left[\mathrm{M}-\mathrm{CH}=\mathrm{CH}_{2}, 18 \%\right]^{+}, 133\left[\mathrm{M}-\mathrm{OCH}_{3}, 20 \%\right]^{+}, 91\left[\mathrm{M}-\mathrm{C}_{6} \mathrm{H}_{5}-\mathrm{CH}_{2}\right.$, $15 \%]^{+}, 77\left[\mathrm{M}-\mathrm{C}_{6} \mathrm{H}_{5}-\mathrm{CH}_{2}, 14 \%\right]^{+}$.

\section{Results and discussions}

In this study a double PEG-drugs derivative, EU-PEG-IBU, was prepared and used as polymeric carrier to enhance the solubility and to minimize gastrointestinal side effects of ibuprofen.

The synthesis of mixed conjugate was achieved by a derivative of the PEG polymer, whose hydroxylic terminals are selectively and reversibly protected groups with different sensitivity to removal (orthogonal protection). The polymeric derivative Cbz-linkerPEG-linker- $\mathrm{NH}_{2}$ (1) was as described by Campaner et al. [22]. This selectively end-modified polymer derivative can be easily conjugated at its extremities with two different molecules, as requested for our purposes. Scheme 1 shows the synthetic strategy for the preparation of Cbz-linker-PEG-linker- $\mathrm{NH}_{2}(1)$.

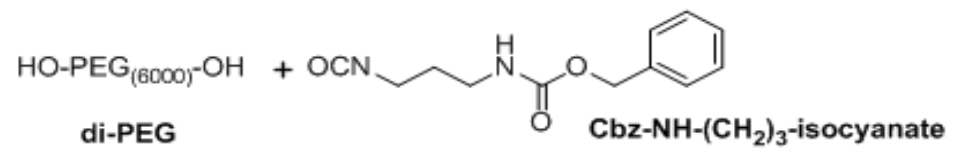

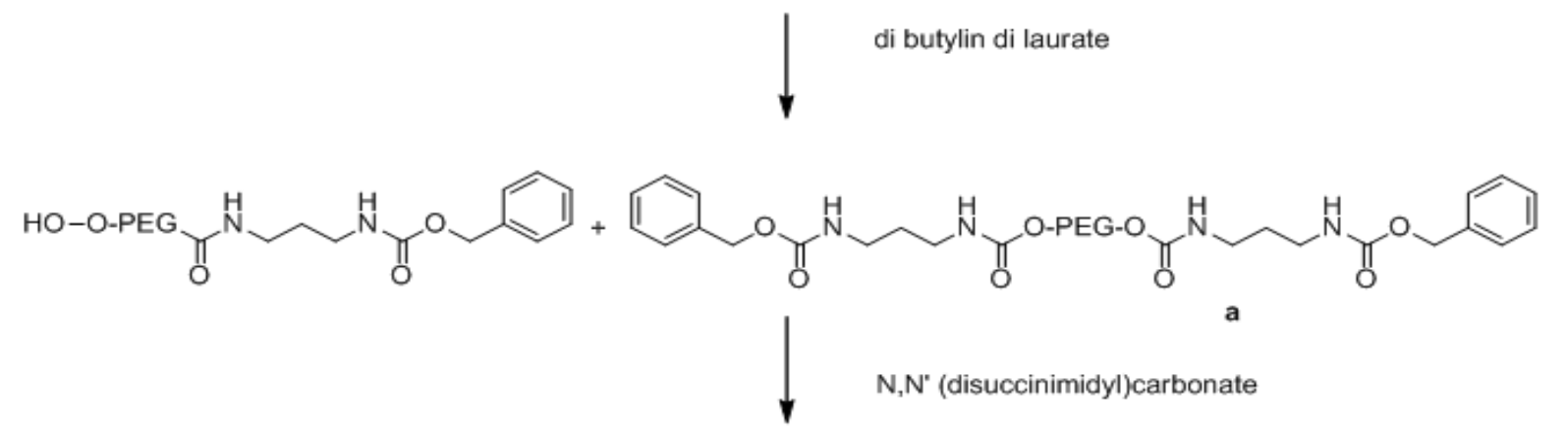<smiles>CCOC(=O)OC(=O)NCCCNC(=O)OCc1ccccc1</smiles>

(1)

Cbz-linker-PEG-linker- $\mathrm{NH}_{2}$

Scheme 1: Scheme of synthesis of Cbz-linker-PEG-linker- $\mathrm{NH}_{2}$

The polymeric derivative selectively modified (1) was used to bind covalently to its ends the drugs ibuprofen and eugenol. Ibuprofen was linked through an amide bond while eugenol trough an ester bond.

Scheme 2 shows the synthetic strategy for the preparation of the final adducts eugenol-linker-PEG-linker-ibuprofen (4). The reaction between the carboxyl group of IBU and the free amino group of the modified polymer (1) led to the synthesis of the compound (2) Cbz-linker-PEG ${ }_{6000}$-linker-IBU by a stable amide linkage. IBU was added under stirring, to a solution of (1) in ACN, in the presence of EDC, HOBT, as coupling agents, and TEA. The HOBT reduced racemization during the synthesis of the amidic bond. The product was obtained with a yield of 95\%, after precipitation in $\mathrm{Et}_{2} \mathrm{O}$, filtration and recrystallization from EtOH hot/ cold. The coupling was achieved using an excess amount of IBU. The success of the reaction was confirmed by the colorimetric TNBS test, evaluating the disappearance of the free amino groups of the compound (2). The TNBS (2,4,6-trinitrobenzene sulfonic 
acid) is a highly sensitive and rapid chemical used for primary amines generating a highly chromogenic product that can be readily

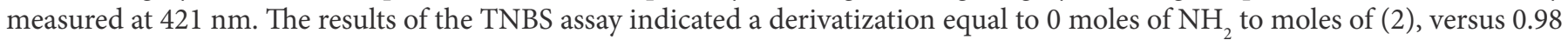
moles of $\mathrm{NH}_{2}$ to moles of (1). In addition, the ${ }^{1} \mathrm{H}$-NMR spectrum showed the set of expected signals, in particular the multiplet at $7.21 \mathrm{ppm}$ is due to the aromatic protons ascribed to ibuprofen, while the doublet at $1.35 \mathrm{ppm}$ is due to the methyl group of IBU adjacent to the amide group $(J=7.34 \mathrm{~Hz})$. The typical chemical shift between 3.53-3.32 ppm of the methylenic protons of PEG and the signals at $7.05(\mathrm{~m} ; 3 \mathrm{H}, 3 \mathrm{NH}$-urethane) confirm the synthesis of the conjugate (2) characterized by a stable amide like linkage.

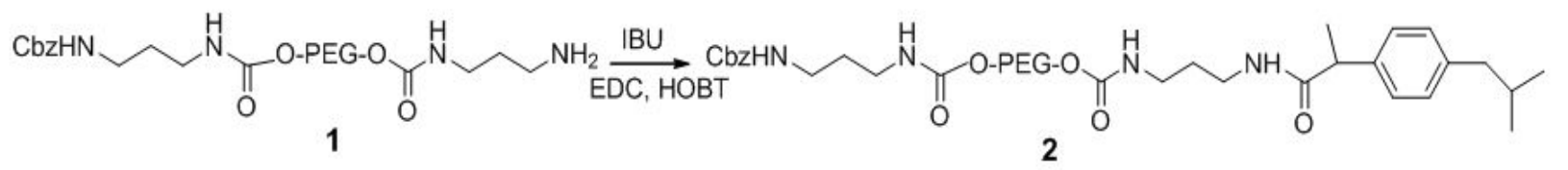<smiles>CCOC(=O)OC(=O)NCCCNC(=O)CCC(=O)NCCCNC(=O)C(C)c1ccc(CC(C)C)cc1</smiles><smiles>CCOC(=O)OC(=O)NCCCNC(=O)CCC(=O)NCCCNC(=O)C(C)c1ccc(CC(C)C)cc1</smiles>

Scheme 2: Scheme of synthesis of eugenol-linker-PEG-linker-ibuprofen

The next step was the deprotection of Cbz protected the amino group of (2) and the reaction with succinic anhydride to obtain the compound (3) with a terminal carboxyl functionality. The removal of the $\mathrm{Cbz}$ has required careful control of the reaction conditions to avoid the undesired detachment of the linker because of the presence of $\mathrm{NH}_{2}$ group free, nucleophilic function, at its end. In fact, due to a probable attack intramolecular and / or intermolecular, was observed a significant reduction of the total amine functionality in neutral conditions. Consequently, the hydrogenolysis of the Cbz group was performed under acidic conditions, carefully optimized, since the protonation of the free amino function has avoided any side reaction and allowed a complete recovery. The full release was confirmed by the TNBS test, evaluating the presence of free amino groups in the compound $\mathrm{NH}_{2}$-linker-PEG-linker-IBU, (Figure 1) it detects a derivatization equal to 0.98 moles of $-\mathrm{NH}_{2}$ per mole of compound. The ${ }^{1} \mathrm{H}$-NMR spectrum shows the disappearance of the signals at $7.34 \mathrm{ppm}$ and $5.01 \mathrm{ppm}$ relative to the Cbz group.<smiles>CC(C)Cc1ccc(C(C)C(=O)NCCCNC(=O)O[Fe]#[P-]OC(=O)NCCCN)cc1</smiles>

Figure 1: Structure of $\mathrm{H}_{2} \mathrm{~N}$-linker-PEG 6000 -linker-IBU (2a)

The conjugation of eugenol by an ester bond to the activated polymer, $\mathrm{NH}_{2}$-linker-PEG-linker-IBU, requires the presence of a carboxylic group. In order to introduce the terminal carboxyl group was used succinic anhydride, since it ensures an excellent degree of functionalization. Furthermore, succinic acid is often used as a spacer arm between the drug and polymer [23-25].

The reaction was conducted in dichloromethane in presence of a large excess of succinic anhydride and DMAP as catalyst (Scheme 1). The carboxylate product (3) was obtained with a yield of $95 \%$, after precipitation in $\mathrm{Et}_{2} \mathrm{O}$, filtration and recrystallization from EtOH hot/cold. The subsequent esterification reaction between the carboxyl group of the activated polymer (3) and the phenolic hydroxyl group of eugenol allowed to obtain the desired adduct (4). The conjugation was carried out in a single step by adding eugenol, under stirring, to a solution of HOOC-linker-PEG ${ }_{6000}$-linker-IBU (3) in ACN in the presence of DCC and DMAP, respectively (Scheme 2). The adduct (4) was obtained with a yield of $94 \%$, after precipitation in $\mathrm{Et}_{2} \mathrm{O}$, filtration and recrystallization from EtOH hot/cold. The absence of the free EU in the adduct was confirmed by RP-HPLC. The content of linked drugs in the conjugate was evaluated by RP-HPLC, on the basis of the release of IBU and EU in alkaline media after $15 \mathrm{~min}$ at $80{ }^{\circ} \mathrm{C}$. This was found to be $100 \%(\mathrm{w} / \mathrm{w})$. The ${ }^{1} \mathrm{H}-\mathrm{NMR}$ spectrum (Figure 2) shows the set of expected signals. In particular, the signals at 7.92 and $7.08 \mathrm{ppm}(J=7.8 \mathrm{~Hz})$ are due to the two amidic protons and two urethanes protons of (4), respectively. The singlet at 3.80 ppm $\left(\mathrm{CH}_{3} \mathrm{O}\right)$, together with the double doublet at 5.06 and $5.18 \mathrm{ppm}\left(\mathrm{CH}-\mathrm{CH}=\mathrm{CH}_{2}, J=1.5,1.4 \mathrm{~Hz}\right)$ confirm the linkage with eugenol and the efficient synthetic route.

In the final conjugate EU-linker-PEG ${ }_{6000}$-linker-IBU (4), EU and IBU molecules were linked through an ester and an amide bond, respectively; since the cleavage of these bonds was likely to occur in plasma, EU and IBU molecules were released.

The hydrolysis rate of the conjugate was studied in vitro in a phosphate buffer solution $\mathrm{pH} 7.4$, and in artificial gastric juice $\mathrm{pH} 1.2$. 
The degradation of (4) was followed by RP-HPLC analysis of the released free drugs.<smiles>C=CCc1ccc(OC(=O)CCC(=O)NCCCNC(=O)OC(=O)OC(=O)NCCCNC(=O)C(C)c2ccc(CC(C)C)cc2)c(OC)c1</smiles>

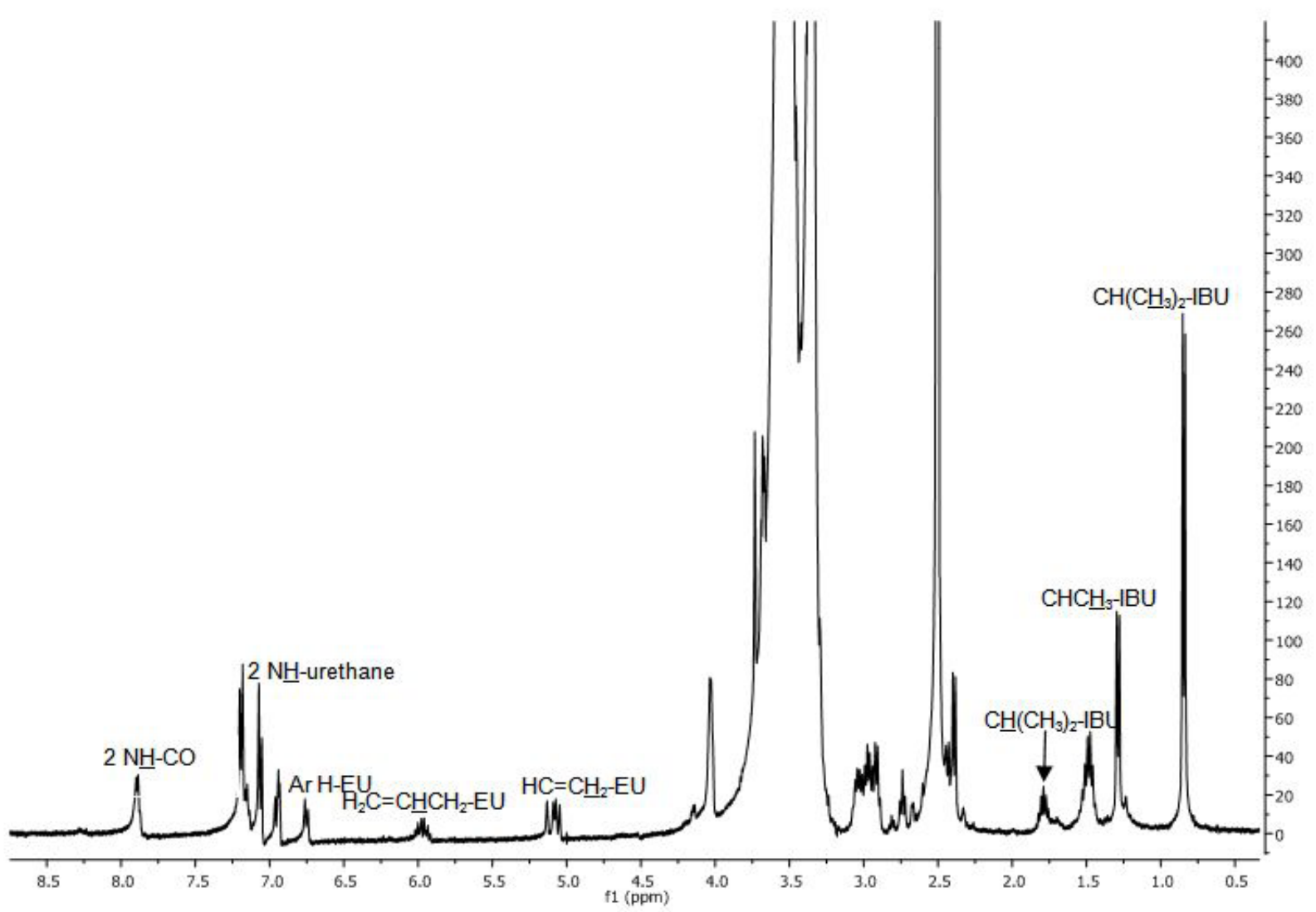

Figure 2: ${ }^{1} \mathrm{H}-\mathrm{NMR}$ in DMSO- $\mathrm{d}_{6}$ di EU-linker-PEG6000-linker-IBU (4)

Figure 3 shows that the hydrolysis rate of the EU-linker- $\mathrm{PEG}_{6000}$-linker-IBU (4) in phosphate buffer solution $\mathrm{pH} 7.4$, at $37^{\circ} \mathrm{C}$ is related to the type of bond; about 50\% of EU and less than $2 \%$ of IBU are released from the polymer over $24 \mathrm{~h}$.

Figure 3 depicts, also, the hydrolytic behavior for the same conjugate in artificial gastric fluid ( $0.32 \%$ of gastric protease) at $\mathrm{pH} 1.2$, $37^{\circ} \mathrm{C}$. Approximately less than $4.8 \%$ of IBU and $15 \%$ of EU were released over $6 \mathrm{~h}$. On the basis of the above data, the hydrolytic stability is also good in gastric juice.

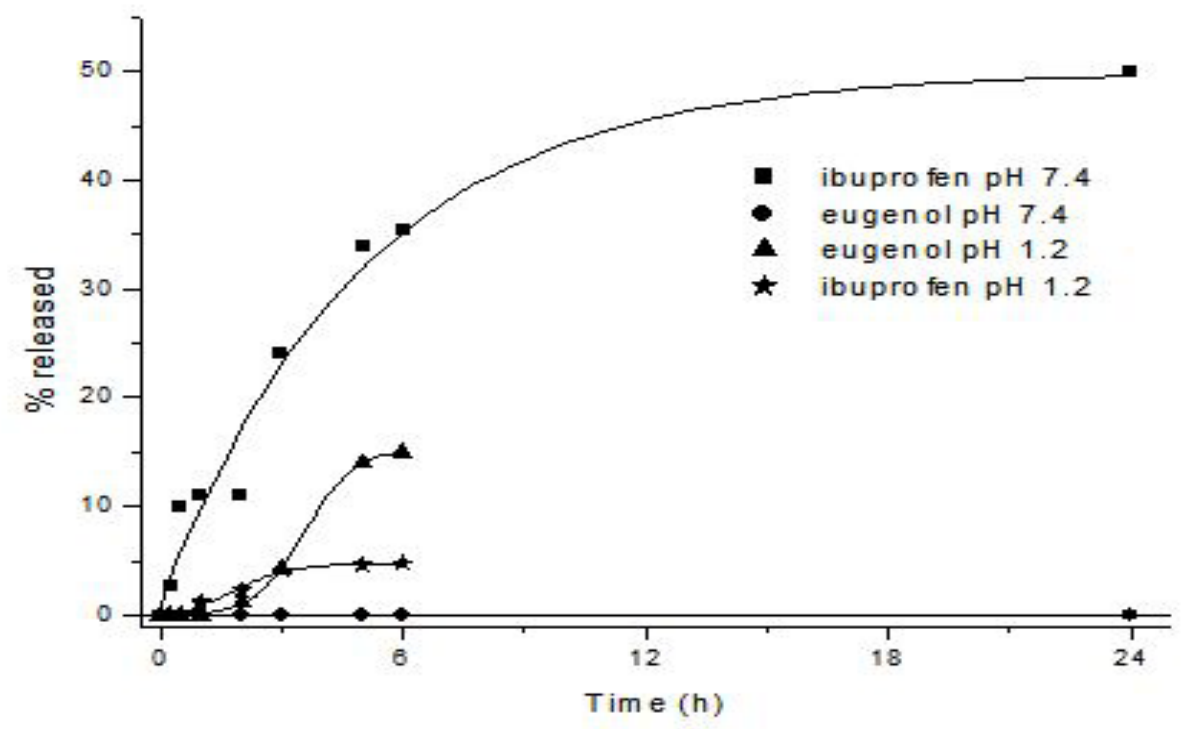

Figure 3: Release of EU and IBU from EU-linker-PEG ${ }_{6000}$-linker-IBU in phosphate buffer solution $\mathrm{pH} 7.4(-)$, in artificial gastric juice $\mathrm{pH} 1.2(------)$ at $37 \pm 0.1{ }^{\circ} \mathrm{C}$ 
The EU-linker-PEG 6000 -linker-IBU therefore, was almost hydrolytically stable in phosphate buffer pH 7.4 (no hydrolysis for IBU), and in simulated gastric medium showing good resistance in the stomach acidic medium.

The macromolecular prodrug ability to release the free drugs was also evaluated in mouse plasma. More than $95 \%$ of linked EU and $87 \%$ of IBU were released from the polymeric conjugate within $24 \mathrm{~h}$ (Figure 4 ). This indicates that the macromolecular conjugate may a good substrate for the plasma enzymatic complex and its capacity to deliver free and active drugs in a prolonged manner. The structure of released EU and IBU was confirmed by mass spectrometry analysis. The molecular ion at $m / z=164 \mathrm{confirmed}$ the presence of EU and the fragments at $\mathrm{m} / z=149$ and 91 were due to the loss of a methyl and of $\mathrm{C}_{2} \mathrm{H}_{3}$ group; respectively. The molecular ion at $m / z=206$ confirmed the presence of IBU and the fragments at $m / z=191$ and 161 were due to the loss of a methyl and a carboxyl group; respectively.

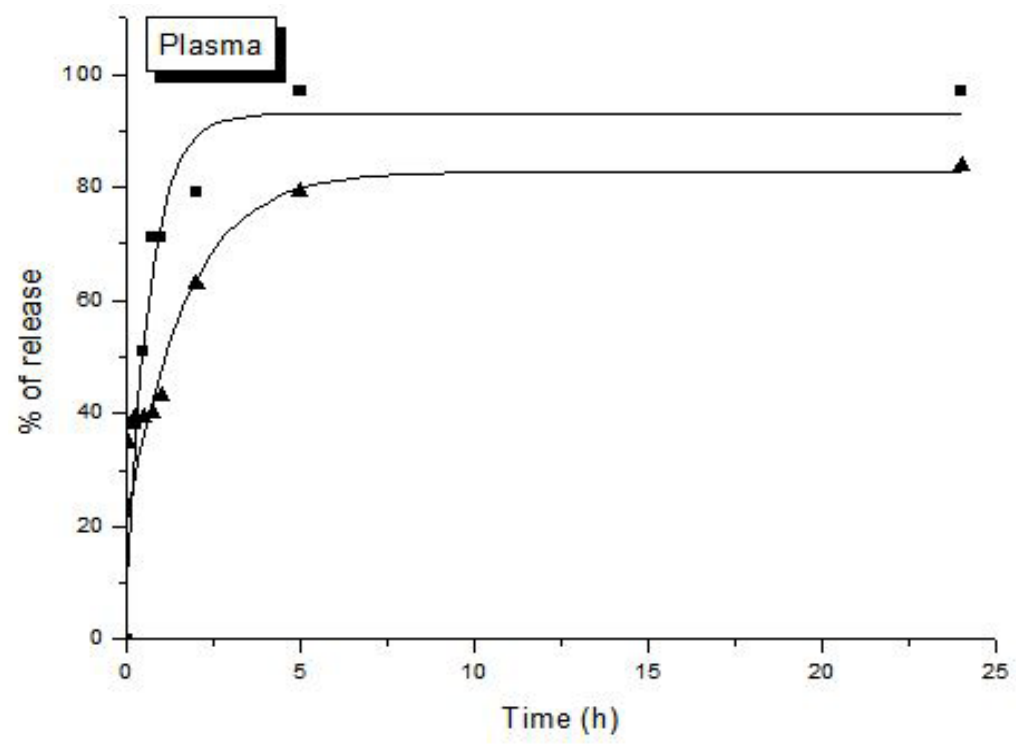

Figure 4: Release of EU and IBU from EU-linker-PEG ${ }_{6000}$ - linker-IBU in mouse plasma at $37 \pm 0.1^{\circ} \mathrm{C}$, - EU, IBU

\section{Graphical abstract}

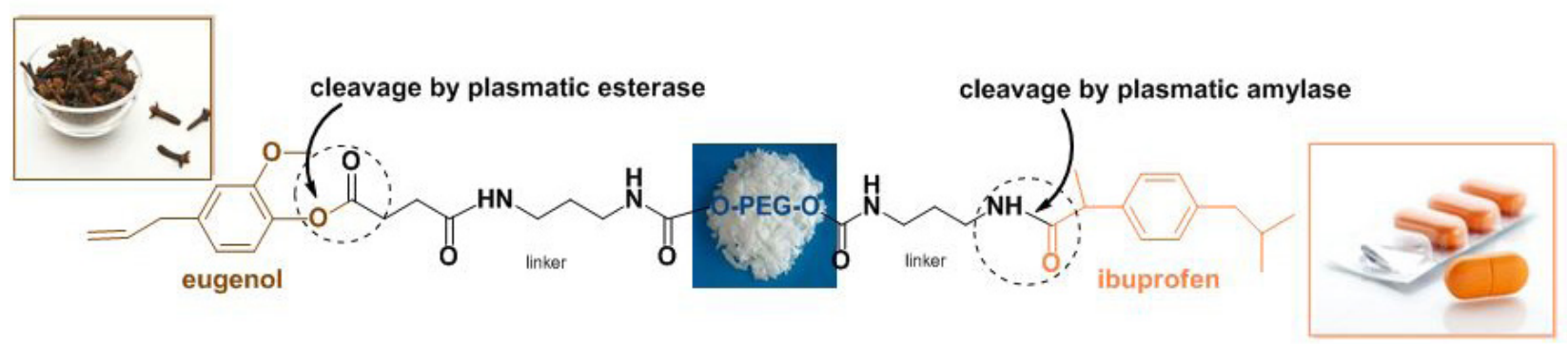

Eugenol and ibuprofene were covalently bound to bi-functionalized PEG, used as molecular carrier of drugs, and the release kinetics of the two bioactive molecules was studied in vitro in buffer solutions and in mouse plasma. The conjugation of two drugs having different pharmacological activities led to a mutual prodrug with synergistic and anti-inflammatory effects and reduced GI irritation.

\section{Conclusion}

On the basis of our previous investigations we studied this new bifunctional, multimeric PEG-based support as a new drug delivery system where two different and synergic drugs were linked on the same biocompatible polymeric support. According to the pharmacodynamic analysis the stability of this new PEG-bis conjugate in artificial gastric fluid was confirmed, while a slow release of the drugs in plasma mouse was also observed.

The conjugation of eugenol with ibuprofen as a reversible prodrug leads to many advantages including stabilization, reduction of irritation, unpleasant smell and versatility of usage. In addition, the biotransformation of the prodrugs into the parent compounds at its target site or sites of activity might be used to achieve rate and time controlled drug delivery of the active entities.

Pharmacological studies will give further data about the most convenient use of these PEGylated molecules in therapy. The conjugation of two drugs having different pharmacological activities should lead to a mutual prodrug with synergistic and antiinflammatory effects and reduced GI irritation. 


\section{References}

1. Pasut G, Veronese FM (2012) State of the art in PEGylation: The great versatility achieved after forty years of research. J Control Rel 161: 461-72.

2. Brocchini S, Godwin A, Balan S, Choi J, Zloh M, et al. (2008) Disulfide bridge based PEGylation of proteins. Adv Drug Deliv Rev 60: 3 -12.

3. Veronese FM (2001) Peptide and protein PEGylation: a review of problems and solutions. Biomaterials 22: 405-17.

4. Greenwald RB, Choe YH, McGuire J, Conover CD (2003) Effective drug delivery by PEGylated drug conjugates. Adv Drug Deli Rev 55: $217-50$.

5. Garavito RM, Malkowski MG, DeWitt DL (2002) The Structures of Prostaglandin Endoperoxide H Synthases-1and -2. Prostag Oth Lipid Mediat 68-69: 129-52.

6. Nayak A, Jain A (2011) In Vitro and In Vivo Study of Poly(ethylene glycol) Conjugated Ibuprofen to Extend the Duration of Action. Sci Pharm 79: $359-73$.

7. Kawai S, Kojima F, Kusunoki N (2005) Recent Advances in Nonsteroidal Anti-Inflammatory Drugs. Allergol Int 54: 209-15.

8. Kean WF, Buchanan WW (2005) The use of NSAIDs in rheumatic disorders 2005: a global perspective. Inflammopharmacology 13: 343-70.

9. Redasani VK, Bari SB (2012) Synthesis and evaluation of mutual prodrugs of ibuprofen with menthol, thymol and eugenol. European J Med Chem 56: 134-8.

10. Zhao X, Chen D, Gao P, Ding P, Li K (2005) Synthesis of ibuprofen eugenol ester and its nanoemulsion formulation for parenteral delivery. Chem Pharm Bull 53: $1246-50$.

11. Zhao XL, Chen DW, Gao P, Luo YF, Li KX (2005) Synthesis, properties and microemulsion formulation of ibuprofen eugenol ester. Pharmazie 60: 883-7.

12. Kamatou GP, Vermaak I, Viljoen AM (2012) Eugenol-From the Remote Maluku Islands to the International Market Place: A Review of a Remarkable and Versatile Molecule. Molecules 17: 6953-81.

13. Morsy MA, Fouad AA (2008) Mechanisms of gastroprotective effect of eugenol in indomethacin-induced ulcer in rats. Phytother Res 22: $1361-6$.

14. Bennett A, Stamford IF, Tavares IA, Jacobs S, Capasso F, et al. (1988) The biological activity of eugenol, a major constituent of nutmeg (Myristica fragrans): Studies on prostaglandins, the intestine and other tissues. Phytother Res 2: 124-30.

15. Trailovic MS,. Robertson PA, Nedeljkovic-Trailovic (2009) Inhibitory effect of eugenol on rat ileal motility in vitro. J Acta Vet 59: 123-31.

16. Lima FC, Peixoto-Neves D, Gomes MD, Coelho-de-Souza AN, Lima CC, et al. (2011) Antispasmodic effects of eugenol on rat airway smooth muscle. Fundam Clin Pharm 25: 690-9.

17. Pramod K, Ansari SH, Ali J (2010) Eugenol: a natural compound with versatile pharmacological actions. Nat Prod Commun 5: $1999-2006$.

18. Zhao X, Chen D, Li K, Wang D (2005) Sensitive liquid chromatographic assay for the simultaneous determination of ibuprofen and ist prodrug, ibuprofen eugenol ester, in rat plasma. Yakugaku Zasshi 125: 733-7.

19. Zhao X, Tao X, Wei D, Song Q (2006) Pharmacological activity and hydrolysis behavior of novel ibuprofen glucopyranoside conjugates. European J Med Chem 41: 1352-8.

20. Zhao XL, Chen DW, Hu HY, Qiao MX, Li L (2008) Activity profile of glycolamide ester prodrugs of ibuprofen. J Shenyang Pharmaceutical University 25: 60-3.

21. Snyder SL, Sobocinski PZ (1975) An improved 2,4,6-trinitrobenzenesulfonic acid method for the determination of amines. Anal Biochem 64: 284-8.

22. Campaner P, Bonora GM, Drioli S (2006) Synthesis of selectively end-modified high- molecular weight polyethyleneglycol. Lett Org Chem 10: 773-9.

23. Giammona G, Puglisi G, Cavallaro A, Spadaro A, Pitarresi G (1995) Chemical stability and bioavailibity of acyclovir coupled to a, $\beta$-poly(N-2-hydroxyethyl)DL-aspartamide. J Control Rel 33: 261-71.

24. Giammona G, Cavallaro G, Fontana G, Pitarresi G, Carlisi B (1998) Coupling of the antiviral agent zidovudine to a polyaspartamide and in vitro drug release studies. J Control Rel 54: 321-31.

25. Buckmann. AF, Morr M, Johansson G (1981) Functionalization of poly(ethylene glycol) and monomethoxy-poly(ethylene glycol). Makromol Chem 182: 137984.

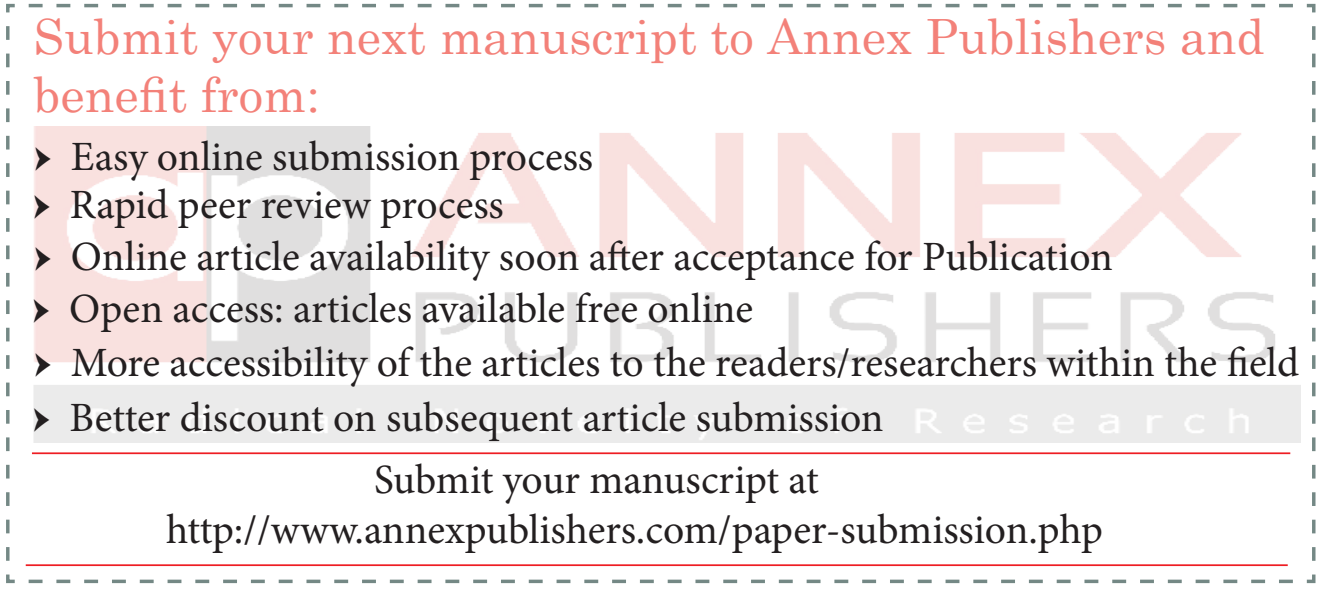

